\title{
DIREITO AO DESENVOLVIMENTO E DIREITO À CIDADE: UMA PROPOSTA DE CATEGORIAS DE DIREITOS HUMANOS UNIVERSAIS COMO PRESSUPOSTOS DE CIDADANIA
}

Alessandra Danielle Carneiro dos Santos Hilário

Graduação em Direito (UNIPÊ), especialização em Gestão Pública (UNIPÊ/TCE -PB), Mestrado em Direito Econômico (UFPB/CCJ/PPGCJ), doutoranda em Direitos Humanos e Desenvolvimento pelo Programa de Pós-Graduação em Ciências Jurídicas do Centro de Ciências Jurídicas da UFPB, Professora Assistente do Departamento de Ciências Jurídicas de Santa Rita/PB/CCJ/UFPB, na área de Direito Constitucional e Administrativo. Email: ad_hjunior@hotmail.com

Maria luiza Pereira de Alencar Mayer Feitosa Possui graduação em História e em Direito (UFPB); mestrado em Ciências Jurídicas (UFPB); aperfeiçoamento em Direito da Regulação (CEDIPRE 0 Universidade de Coimbra); doutorado em Ciências Jurídico-Econômicas (Universidade de Coimbra, Portugal) e pós-doutorado em Direito, Estado e Sociedade pela Universidade Federal de Santa Catarina-UFSC, Brasil. É atualmente Diretora do Centro de Ciências Jurídicas da UFPB. É bolsista de produtividade em pesquisa do CNPQ. Email:mluizalencar@gmail.com

\section{Resumo}

Este artigo aborda o Direito à Cidade ( $\mathrm{DaC})$, em uma dimensão conceitual e ampla, e sua relação dialética com a Declaraçáo Universal dos Direitos Humanos de 1948 e as respectivas categorias de universalismo e relativismo cultural. $\mathrm{O} \mathrm{DaC}$ é capitulado como uma das categorias do Direito Humano ao Desenvolvimento dentre os compartimentos de Direitos Humanos que descendem da Declaraçáo Universal de Direitos Humanos. Atrelada a essa premissa, a discussão sobre as teorias de universalismo e relativismo cultural trazem à baila importantes questionamentos e consideraçóes quanto à condiçáo do $\mathrm{DaC}$, visto que, em sua concepção atual e calcado por uma herança maléfica do neoliberalismo, tal direito demonstrou a necessidade de uma ação impositiva do Estado, dada a sua natureza de direito humano fundamental de terceira dimensão. Por meio do $\mathrm{DaC}$, usufrui-se de direitos econômicos, sociais e culturais, demandando uma açáo positiva do Estado como garantia de observância desse direito humano. Nesse viés, relevantes são as discussóes sobre o conceito de direito, moral, liberalismo, efetividade de direitos humanos e teorias de universalismo e relativismo culturais em dialética com o $\mathrm{DaC}$ e sua complexidade. 
Parte-se do pressuposto de que a Declaração Universal dos Direitos do Homem e as demais Declaraçóes das quais descendem têm caráter universalista (não obstante críticas), todavia, nessa seara, é imprescindível um exame mais acurado do conceito, previsão, garantia e efetividade de direitos humanos fundamentais, o que pode conduzir a uma aplicação mista das teorias universalista e relativista quando analisadas sob a ótica dos institutos referidos. O Direito Humano ao Desenvolvimento $(\mathrm{DaD})$ pressupóe noçóes de sustentabilidade socioambiental e de democracia econômica, com participação qualificada dos sujeitos sociais (cidadania ampla), encaradas em perspectiva contínua e articulada, como norteadores do processo de desenvolvimento.

\section{Palavras-chave}

Direito à cidade; Desenvolvimento; Universalismo; Relativismo.

\section{Abstract}

This article discusses the Right to the City, in a conceptual dimension and wide, and his dialectical relationship with the Universal Declaration of Human Rights of 1948 and its universalism and cultural relativism categories. The Right to the City ( $\mathrm{RtC}$ ) is capitulated as one of the categories of the Human Right to Development from the compartments on Human Rights to descend from the Universal Declaration of Human Rights. Linked to this assumption, the discussion of universalism and cultural relativism theories bring to the fore important questions and considerations as to $\mathrm{RtC}$ condition, since in its current design and trampled by an evil legacy of neoliberalism, this right has demonstrated the need for authoritative action of the State, given the nature of fundamental human right of the third dimension. Through $\mathrm{RtC}$, boasts up of economic, social and cultural rights, requiring a positive action of the state as compliance guarantee this human right. In this bias, relevant are discussions about the concept of law, morality, liberalism, effectiveness and universality of human rights theories and cultural relativism in dialectic with the RtC and its complexity.

It starts from the assumption that the Universal Declaration of Human Rights and other statements which have descended universality (despite criticism), however, this harvest, it is imperative closer examination of the concept, forecast, guarantee and effectiveness fundamental human rights, which may lead to a mixed application of universalistic and relativistic theories when analyzed from the perspective of these institutes. The $\mathrm{Hu}-$ man Right to Development ( $\mathrm{RtD}$ ) presupposes notions of environmental sustainability and economic democracy, with qualified participation of social subjects (wide citizenship), seen continuous and articulated perspective as guiding the development process.

\section{Key words}

Right to the City; Development; Universalism; Relativism. 


\section{Introdução}

A cidade é o lugar onde o indivíduo se realiza como pessoa, trabalha, constitui família, relaciona-se socialmente, aufere ganhos pela produção laboral, dispende seus recursos, educa-se e profissionaliza-se. O espaço urbano é o lugar de promoção da estruturaçáo social do território, onde ocorrem manifestaçôes culturais e sociais e são disponibilizados os meios de consumo coletivo e onde incidem os processos de produçáo e reproduçáo do capital, transformando as cidades em produto da sociedade capitalista, palco de manifestação da luta de classes, decorrente da exploração de trabalhadores.

Neste contexto, surgem as discussōes em torno do Direito à Cidade e seus papéis. A questão urbana, na crise atual das cidades mundiais, volta à tona e traz a preocupação com a consolidaçáo de um $\mathrm{DaC}$ capaz de intervir no tradicional processo de urbanização e desconstruir o artifício espoliador, influenciado pelo liberalismo, o qual marcou a formaçáo das cidades ao longo dos anos. Em perspectiva positiva, trata-se de um ramo do direito, de natureza coletiva, voltado para garantir a fruição dos recursos urbanos postos à disposição de seus moradores, porém, em visão holística, trata-se do direito capaz de reinventar, modificar e alterar a cidade e os citadinos, garantindo-lhes cidadania econômica e social, conforme padróes de necessidade e de prioridades coletivamente designados, respeitando a relevância da figura do cidadão/morador como elemento central do processo. Assim, o $\mathrm{DaC}$ possui direta vinculação com os direitos econômicos, sociais e culturais, previstos no Pacto Internacional dos Direitos Econômicos, Sociais e Culturais das Naçôes Unidas (PIDESC), tendo como ponto de conexáo o direito ao usufruto desses valores, no espaço urbano, sem perder de vista os direitos individuais e os direitos difusos de solidariedade.

A perspectiva aqui apontada conduz, ainda, a um vínculo permanente entre o $\mathrm{Di}$ reito à Cidade e os Direitos Humanos do e ao Desenvolvimento (DdD e $\mathrm{DaD}^{1}$, respectivamente) positivados nos Pactos Internacionais das Naçóes Unidas. O desenvolvimento é visto como processo econômico, social, cultural e político abrangente, que objetiva o bem-estar da população através de sua participação no usufruto de tais direitos de forma equitativa e holística.

Há uma necessária convergência de análise entre o $\mathrm{DaC}$ e o $\mathrm{DaD}$, no sentido de que, diante do colapso atual das cidades (pelo modelo contemporâneo de urbanizaçáo), o indivíduo/cidadão passa a ser o referencial para a fruiçáo desse processo de desenvolvimento. Ele é (ou deveria ser) a principal força motriz do fenômeno de urbanizaçáo dos espaços, bem como da instituiçáo e aplicação de políticas públicas capazes de favorecer o interesse coletivo, no sentido da garantia de bem-estar ou do desenvolvimento humano, entendido

1 Abreviaturas cunhadas pela Profa. Dra. Maria Luiza Alencar Mayer Feitosa, na obra Direitos Humanos de Solidariedade: avanços e impasses. Curitiba: Appris, 2013. 
como processo múltiplo e interdisciplinar, de vertentes socioeconômica, cultural e política, de modo a consentir a maximização de suas capacidades e valores como seres humanos, no espaço citadino. A referência ao Direito do Desenvolvimento vai compreendê-lo como ramo do direito econômico consubstanciado em estratégias e medidas adotadas pelos governos, na esfera estritamente econômico-jurídica, para garantir a produção dos meios econômicos indutores do desenvolvimento. Por outro lado, convergindo o $\mathrm{DaC}$ com o $\mathrm{DaD}$, pode-se chegar aos procedimentos democráticos de escolhas, que respeitam as tendências e peculiaridades locais. A conjugação dos três ramos jurídicos aqui apontados vai se revelar importante para a consecução das metas de desenvolvimento plural e includente, no contexto territorial urbano.

A questấo que se póe quando se categoriza o $\mathrm{DaC}$ como um direito humano (ao desenvolvimento - $\mathrm{DaD}$ ) refere-se a uma análise desse direito em relaçấo às teorias de universalismo ou relativismo cultural. Considerando que a enunciação dos direitos na Declaração de Direitos Humanos e demais Declaraçóes e Pactos foi feita de forma universal, isto é, foram previstos direitos universais indistintamente a todas as categorias de pessoas, e, considerando as peculiaridades culturais de cada sociedade ou País, cabe discutir a viabilidade da aplicação das teorias do universalismo ou relativismo culturais, notadamente em relação ao $\mathrm{DaC}$ e $\mathrm{DaD}$. A discussão permeará necessariamente questôes referentes à efetividade dos direitos humanos e seus obstáculos (a exemplo, na temática específica, do liberalismo e neoliberalismo) como pressupostos do exercício de uma cidadania ampla.

\section{0 Direito à Cidade no Contexto dos Direitos Humanos: Configuração de Categorias}

O Direito à Cidade é um ramo do Direito que se coliga diretamente com os direitos humanos do desenvolvimento e ao desenvolvimento. Abrange conquistas do constitucionalismo econômico, que dáo lastro ao direito do desenvolvimento, ao tempo em que pressupóe a participação do indivíduo nas decisōes relativas ao desenvolvimento econômico, social, cultural e político, como expressóes da realizaçáo plena de direitos humanos e das liberdades fundamentais. São direitos exercitáveis e tornados factíveis no espaço no qual os indivíduos fixam sua moradia e desenvolvem suas atividades. Imprescindível a concepção do Direito à Cidade e configuração de sua condição ou natureza quanto aos direitos humanos.

\subsection{A Cidade, o Urbano e o Direito à Cidade}

Henri Lefevbre é expoente vanguardista nas matérias relativas ao estudo de cidade, urbes, urbano e também na compreensão do alcance do chamado Direito à Cidade, tendo focado sua análise na perspectiva da sociologia urbana e apontando preliminarmente 
uma linha divisória entre os termos 'cidade' e 'urbano' (2001, p. 46). Cidade seria uma expressão pautada em perspectiva mais material, concernente à sua paisagem e formas arquitetônicas, enquanto que o urbano seria a relação dialética e imaterial, vinculada à comunidade e à sociedade que nela se inserem, de natureza mutuamente interferente em áreas diversas, dos pequenos grupos (famílias e corporaçóes) aos grandes grupos (como Estado, Igreja e sociedade), em contato com a cultura e as leis.

Nesse sentido, a cidade seria uma obra (e não um produto) resultante de açóes humanas sequenciadas por essas relaçóes, por isso, não poderia (ou, pelos menos, não deveria) ser encarada como mercadoria destinada à comercialização (BAVA, 2013, p. 4-5), não obstante LefeVbre (2001, p. 62-63) náo subestime a ação do poder de mercado sobre ela. Não se olvide, entretanto, que, para Lefevbre, mesmo o aspecto material da cidade admite significados que os identificam com a ideologia e configuração desta, ou seja, as próprias estruturas arquitetônicas retratam o aspecto urbano da cidade e as relaçóes (inclusive de poder) entre os seus atores, aí compreendidos indivíduos e grupos, Estado e mercado. É de se destacar, nesse contexto, o processo de urbanização, categoria necessária ao estudo do Direito à Cidade, com quem guarda íntima relação. Para Lefevbre, o processo de urbanização das cidades teve início simultaneamente ao processo de industrialização, responsável pelas novas configuraçóes da cidade e sua relação com o campo (ou seja, urbano versus rural), assim como pelos problemas nela vivenciados, no tocante ao seu crescimento desordenado e ao modo de vida das pessoas, tornando-se ponto de atração de riquezas, conhecimento, técnicas e obras² (Lefevbre, 2001, p. 3). Como consequência dessa relação simbiótica ${ }^{3}$ de causa, efeito e interaçóes constantes, a cidade conjuga duas vertentes importantes: como obra, dotada de valor de uso, e como produto, munida de valor de troca. Nesta última análise de LEFEVbre se encontra a origem da concepção contemporânea delineada por DAvid HaRvey de 'cidade como mercadoria' (HARVEY, 2013), parecendo desvanecer-se, assim, da figura de direito humano.

Para Lefevbre, o processo de industrialização expressou o início da fase do capitalismo (sob a influência do neoliberalismo), entendido como modelo de regência da vida econômica nas cidades. Atente-se para o destaque dado ao seu valor de troca, que pontua, em marco temporal e histórico, o começo da crise nas cidades, não obstante a existência de um período progressivo de explosão e de proliferação de centros urbanos, permeados por açóes voltadas para a manutençáo do poder econômico, cujos grupos dispunham de soluçóes para o enfrentamento dos problemas urbanos sob a ótica capitalista, em associação com o Estado.

2 Em lefevbre, 'obra' assume o significado de resultado das açóes humanas.

3 Toma-se de empréstimo a simbiose como um dos tipos de relaçóes entre duas espécies que se aliam ou se conjugam para galgarem dado benefício, entretanto, de maneira desproporcional. 
Sim, esta cidade que atravessa tantas vicissitudes e metamorfoses, desde seus núcleos arcaicos que seguiram de perto a aldeia, essa forma social admirável, essa obra por excelência da práxis e da civilização se desfaz e se refaz sob nossos olhos. [...] Quando emergiram os problemas de conjunto, sob o nome de urbanismo, foram eles subordinados à organização geral da indústria. Atacada ao mesmo tempo por cima e por baixo, a cidade se alinha pela empresa industrial; figura na planificação como engrenagem; torna-se dispositivo material próprio para se organizar a produção, para controlar a vida quotidiana dos produtores e o consumo dos produtos. Rebaixada para o nível de meio, ela estende a programaçâo para o lado dos consumidores e do consumo; serve para regulamentar, para ajustar uma sobre a outra, a produção das mercadorias e a destruição dos produtos através da atividade devoradora chamada 'consumo'. (LEFEVBRe, 2001, p. 76).

O cenário da industrialização e seu processo se constituem em pano de fundo, panorama no qual se erigirá o Direito à Cidade, como pressuposto jurídico-teórico do desenvolvimento econômico harmônico e concatenado à compreensão da interface desse ramo normativo com o DaD e DdD. Nesse sentido, Lefevbre vincula a ideia de base do DaC às necessidades sociais, não individualmente tomadas como potencialidade de consumo isolado e seletivo de produtos e bens, mas em perspectiva que transcende essa individualidade e assume proporçóes coletivas e difusas. Refere-se a um sentimento de solidariedade preocupado com o bem-estar geral, no presente e no futuro. A cidade, objeto do Direito à Cidade, precisa ser entendida no contexto do espaço urbano e de suas implicaçóes socioeconômicas, políticas e culturais, postulando, em todo caso, a construção de um locus capaz de distribuir, ao menos de forma aproximada, equitativa e qualitativamente, os recursos necessários à fruição dos direitos sociais ${ }^{4}$ nesse território que representa lugar de realização de vida e pressuposto do desenvolvimento como direito fundamental humano (PIOVESAN, 2004, p.22). Na perspectiva proposta por LefeVbre, o Direito à Cidade se relaciona diretamente com uma atividade de recriação, não havendo mais a possibilidade de retorno aos formatos anteriores de cidade. A reconstrução da cidade e dessa nova urbanidade dar-se-ia segundo critérios ditados pelas atuais necessidades, descomprometidas das necessidades capitalistas de reinvestimento dos lucros, mas inspiradas por um direito fundamental e humano ao desenvolvimento plural no qual os direitos sociais (educação, saúde, moradia, alimentação, trabalho, seguridade, segurança, entre outros) assumem caráter de prestação positiva efetiva, assumida preponderantemente pelo Estado,

4 São referidos apenas os direitos sociais em virtude da concordância com o entendimento de FLÁvia Piovesan acerca da necessária efetividade dos direitos individuais como pressuposto à efetividade dos direitos sociais, pelo que ambos se revelam indissociáveis dentro da categoria de dimensóes de direitos fundamentais. Ver: pIOvesan, Flávia. Direitos sociais, econômicos e culturais e direitos civis e políticos. SUR - Revista Internacional dos Direitos Humanos. Ano I, Número I, 2004, p. 22. 
mediante participação destacada e decisiva do indivíduo citadino (onU, Declaração de Viena, 1993).

O Direito à Cidade, relacionado ao conjunto de direitos constitucionais fundamentais e humanos insertos na Constituição Federal do Brasil de 1988, é capitulado pela doutrina e a jurisprudência constitucional como direito de terceira dimensão, que transcende a individualidade do ser humano e deve ser programado em atenção às presentes e futuras geraçôes, importando em preocupaçôes para além do espectro individual egoístico. Para SARLET, trata-se de um direito que envolve, de forma cumulativa e não geracional (SARLET, 2006, P. 293), a proteção de direitos individuais civis e políticos e de direitos sociais em sua amplitude (econômicos, culturais e ambientais), com clara conotação de direito material, inserido na lista dos direitos fundamentais e humanos, e, na vertente social, estreitamente vinculado ao Direito humano ao Desenvolvimento, que se realiza pela efetividade dos direitos sociais, econômicos e culturais (sENGUPTA, 2002, pp. 70 e 82) .

$\mathrm{O} \mathrm{DaC}$, nas suas relaçóes com o $\mathrm{DdD}$ e o $\mathrm{DaD}$, apresenta interfaces, convergências e divergências, assumindo relevância a necessária clareza conceitual acerca de expressóes como desenvolvimento, crescimento econômico, desenvolvimentismo e $\mathrm{DdD}$ e $\mathrm{DaD}$, considerados em relação ao $\mathrm{DaC}$ e sua efetivação.

\subsection{DaC no Contexto do Direito do Desenvolvimento $(D d D)$ e do Direito Huma- no ao Desenvolvimento $(\mathrm{DaD})$}

Contextualizada a topografia do Direito à Cidade relativa aos direitos humanos e fundamentais, cabe tecer algumas consideraçóes sobre as relaçôes entre o Direito à Cidade $(\mathrm{DaC})$ e os Direitos ao e do Desenvolvimento ( $\mathrm{DaD}$ e $\mathrm{DdD})$, incluindo temas como crescimento econômico, desenvolvimento e desenvolvimentismo.

Nas suas vinculaçóes econômicas, o desenvolvimento se mistura às ideias de progresso e de crescimento econômico; no campo jurídico, o desenvolvimento foi admitido ao catálogo dos direitos humanos de terceira dimensão, como direito da pessoa humana, internacionalmente tutelado, tendo como marco inicial o Pacto Internacional dos Direitos Econômicos, Sociais e Culturais da ONU (PIDESC), adotado e ratificado em 16 de dezembro de 1966, com vigência a partir de janeiro de 1976. Esse iter revela que a primeira perspectiva social de desenvolvimento ocorreu no campo econômico, tendo representado

5 arjun SEngupta afirma que o Comitê dos Direitos Econômicos, Sociais e Culturais examinou o direito à moradia adequada e declarou que o mesmo deveria ser visto como o direito a residir em algum local em segurança, paz e dignidade. Isso deveria ser assegurado a todas as pessoas, independentemente de renda ou disponibilidade de recursos econômicos, porém, ARJUN SENGUPTA complementa afirmando que, para melhor se alocar como direito ao desenvolvimento, o direito à moradia adequada teria que pressupor a liberdade de escolha, consubstanciada na participação na decisão sobre o local tido seguro. 
o início de um processo de transmutação da ideia de desenvolvimento do contexto do crescimento econômico ou dos propósitos governistas de desenvolvimentismo para a seara dos Direitos Humanos (feitosa, 2013, p. 172). Da ênfase nas políticas econômicas e nas estratégias de equilíbrio de contas públicas, comércio internacional, industrialização, reestruturação de setores econômicos, típicas do $\mathrm{DdD}$, para a cobertura das crescentes demandas humanas que transcendiam os aspectos econômicos e nacionais, alcançando o nível de tutela internacional, características do $\mathrm{DaD}$, ganha relevo a temática de efetividade de direitos econômicos, atrelados aos direitos sociais e culturais, dando aos primeiros um caráter mais instrumental à realização dos últimos.

Nesse itinerário estaria, em apertada síntese, o percurso entre o direito do desenvolvimento e o direito ao desenvolvimento. A mudança se torou mais evidente quando os aspectos econômicos do desenvolvimento começaram a perder fôlego, impulsionados pelo agudizamento dos conflitos nas relações Norte-Sul e nas relações dos países em desenvolvimento entre si e pelo avanço do processo de globalizaçáo dos mercados, tendo ganhado projeção, em contrapartida, os aspectos plurais e transversais da abordagem de desenvolvimento, que passou a perceber as demandas humanas, superando o contexto macroeconômico; assim, entram em cena temas como o respeito às minorias, a autodeterminação dos povos e sua identidade social e cultural, para além da questáo da circunscrição nacional ou regional de políticas econômicas permeáveis à proteção internacional. (Feitosa, 2013, p. 173).

Assim, a ideia de desenvolvimento avança a partir de um arcabouço de políticas econômicas que, em ação plural e complexa, promovem o bem-estar dos indivíduos, nos campos econômico, social, cultural e político. Dessa percepção, comum ao DdD, as políticas devem mirar os indivíduos e grupos sociais, tidos como efetivos participantes da programação do desenvolvimento, através da distribuição/fruição equitativa e justa dos recursos advindos da realização dos DESC, conforme previsto na Declaração sobre o Direito ao Desenvolvimento da ONU (onu, 1986). Neste ponto reside a raiz do DaD, provocando a mudança de perspectiva do desenvolvimento, antes ligado aos aspectos economicistas e divorciado dos compromissos de bem-estar, podendo ser capitulado como um direito econômico, e, posteriormente, percebido como um direito humano, orientado à consecução da realização humana, em áreas plurais, porém com foco em sua efetividade real, tendo, nesta última perspectiva, o Estado como importante promotor, porém não o único a figurar nessa relação.

A visão do desenvolvimento como direito humano, em realidade, abriu uma dicotomia de direitos, não concomitantes em sua origem, mas diferentes em foco e dimensão. FEITOSA passou a distingui-los em dois campos jurídicos claros: o DdD, no contexto do Direito Econômico, e o DaD, no campo dos direitos humanos (FeItosa, 2013). Esta 
percepção é inovadora porque destaca, em esfera nacional e internacional, projeçôes diversas das anteriormente tratadas. Ilustrativamente, podem ser assim visualizados:

\section{Figura 1 - Relação Desenvolvimento x DdD e DaD}

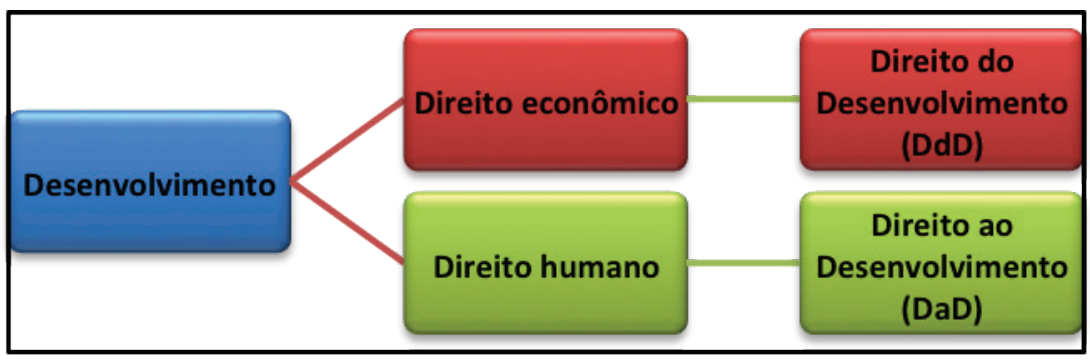

Ambos possuem raiz comum no desenvolvimento, mas diferem pela área em que se inserem e pela amplitude que alcançam. O DdD refere-se ao direito econômico constitucional, manejado no âmbito das interações entre Estado e agentes de mercado (FEITOSA, 2013, pp.173-174), porém com objetivo de atendimento ao interesse social no tocante aos DESC, através de processos e estratégias econômicas que lidem com fenômenos socioeconômicos de caráter promocional (prestação positiva do Estado ${ }^{6}$ ) referidos, por exemplo, nos artigos $6^{\circ}$ (Direitos Sociais) e 170 (Ordem Econômica), da Constituiçáo Federal do Brasil de 1988 (sArLet, 2006, p. 293). Significa que o DdD pode ser encontrado e positivado em leis e codificaçóes formais.

Por sua vez, o DaD teria amplitude conceitual mais acentuada que o $\mathrm{DdD}$, posto se inserir no campo dos direitos humanos inalienáveis e indisponíveis, à dimensão da coletividade e dos direitos de solidariedade (PEIXINHO e FERRARO, p. 6957), portanto, dos direito dos povos (FEITOSA, 2013, p. 174), servindo à realização da dignidade da pessoa humana, em seu sentido de proteção mais do que promoção. No entanto, ampliado no campo conceitual e principiológico, seria reduzido no terreno dogmático, havendo mesmo quem o considere um metadireito ou uma abordagem do desenvolvimento conforme a visão dos direitos humanos (sengupta, 2002, p. 66). Ambos, DdD e DaD, podem interagir no contexto da cooperação internacional e das políticas de desenvolvimento econômico, estando a distinção na crescente participaçáo popular, assim, o $\mathrm{DaD}$ se volta

6 Segundo SARLET, sobre os DESC, direitos de segunda dimensão na tradicional classificação dos direitos fundamentais em dimensốes, incide uma conduta do Estado que se denomina de prestaçáo positiva, a significar que, para sua real efetivação, é imperioso um agir do Estado no sentido de promover a fruição desses direitos aos seus administrados. É justamente aí que se circunscreve um dos grandes desafios dos DESC. SARLET, cit. 
para a satisfação de indivíduos, coletividades ou povos, que representam o centro da tutela humana do direito. No $\mathrm{DaD}$, a perspectiva da proteção assume contornos transnacionais, intergeracionais e difusos, conexos à humanidade em sua dimensão mais amplificada. Pontuando as diferenças entre o DaD e DdD, Arjun Sengupta afirma que:

O direito ao desenvolvimento como um direito humano traz à tona questóes sobre as quais o mundo tem estado fundamentalmente dividido tais como as relacionadas às ideias de justiça, igualdade e prioridades da política internacional. [...] Em função de sua associação com essas questôes relacionadas à justiça e igualdade, realizar o direito ao desenvolvimento é fundamentalmente diferente das políticas convencionais e programas para o desenvolvimento, vistos como o aumento do PIB, o suprimento das necessidades básicas ou melhoria do índice de desenvolvimento humano. [...] Se o desenvolvimento depende de políticas e não apenas do espontâneo jogo das forças do mercado, então qualquer abordagem que facilite, mesmo que não assegure, mais que outra, a formulação, adoção e implementação de políticas apropriadas para realizar os objetivos do desenvolvimento seriam tidas como superiores. (SEgUnPTA, 2002, pp. 66 e 71$)$.

Do exposto sobre $\mathrm{DdD}$ e $\mathrm{DaD}$, cabe salientar que o $\mathrm{DdD}$ seria, como mencionado, um direito de menor amplitude e alcance do que o $\mathrm{DaD}$, tendo caráter instrumental à realização do $\mathrm{DaD}$. Essa inferência é resultado da leitura interpretativa da própria Declaração sobre o Direito ao Desenvolvimento em seu art. $2^{\circ}, \$ 3^{\circ}$, art. $4^{\circ}$ e art. $6^{\circ}, \$ 3^{\circ}$, que remete aos Estados à formulação de políticas, inclusive econômicas, para efetivação dos DESC com foco na realização do desenvolvimento, portanto, do $\mathrm{DaD}$. Nessa dinâmica, o desenvolvimento assume viés de bem jurídico plural em fruição e não apenas o direito a um processo de desenvolvimento.

7 Art. $2^{\circ}, \$ 3^{\circ}$. Os Estados têm o direito e o dever de formular políticas nacionais adequadas para o desenvolvimento, que visem ao constante aprimoramento do bem-estar de toda população e de todos os indivíduos, com base em sua participação ativa, livre e significativa, e no desenvolvimento e na distribuição equitativa dos benefícios daí resultantes. (grifo nosso).

Art. $4^{\circ}$. Os Estados têm o dever de, individual e coletivamente, tomar medidas para formular as políticas internacionais de desenvolvimento, com vistas a facilitar a plena realização do direito ao desenvolvimento. É necessária açấo permanente para promover um desenvolvimento mais rápido dos países em desenvolvimento. Como complemento dos esforços dos países em desenvolvimento, uma cooperaçấo internacional efetiva é essencial para prover esses países de meios e facilidades apropriados para incrementar seu amplo desenvolvimento. (grifo nosso).

Art. $6^{\circ}, \$ 3^{\circ}$. Os Estados devem tomar providência para eliminar os obstáculos ao desenvolvimento resultante da falha na observância dos direitos civis e políticos, assim como dos direitos econômicos, sociais e culturais. (grifo nosso). 


\section{Figura 2 - Relação funcional DaD, DdD, Desc e Desenvolvimento}

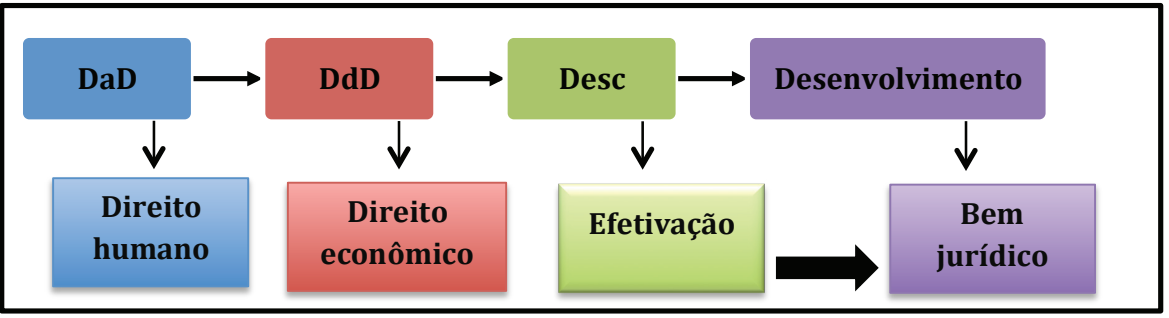

Neste trabalho, os conceitos de $\mathrm{DdD}$ e $\mathrm{DaD}$ são de extrema relevância para se inferir que, quando a adoção de políticas públicas (DdD) não consegue ser suficiente para gerar satisfação de DESC, com ações voltadas para a redução das desigualdades sociais e regionais, bem como a progressiva eliminação da exclusão social (justiça e igualdade ${ }^{8}$ ), no sentido da realização de um desenvolvimento plural ( $\mathrm{DaD})$, verifica-se apenas simples crescimento econômico (setorial) ou, no máximo, um contexto de desenvolvimentismo, que, embora programado pelos governos, não se afigura de modo estrutural. Por sua vez, o desenvolvimentismo seria considerado um "projeto singular e sequencial de crescimento ou acumulação de riquezas para posterior distribuiçáo" contrapondo-se à noção de desenvolvimento que importa, por sua vez, em um processo plural de maximização de fruição de DESC e de capacidade com vistas à "imediata distribuição das riquezas" (FEITOSA, 2013, p. 224). CARLA RISTER (2007, p. 2) corrobora esse entendimento ao afirmar, citando EROS GRAU (1981, p. 7), que "a ideia de desenvolvimento supóe [...] um processo de mobilidade social contínuo e intermitente [...] acompanhado da elevação do nível econômico e do nível cultural-intelectual comunitário”.

A partir destas premissas, chega-se ao ponto central deste item, que é a abordagem das interfaces entre $\mathrm{DdD}, \mathrm{DaD}$ e $\mathrm{DaC}$. Considerando que a Declaração sobre o Direito ao Desenvolvimento (ONU, 1986) condiciona, em seu artigo $1^{\circ}, \$ 1^{\circ}$, o $\mathrm{DaD}$ à participação dos indivíduos e povos no desenvolvimento socioeconômico, cultural e político; considerando que o Direito à Cidade, cujo objeto é a própria cidade, envereda sua investigação pelo espaço urbano e suas implicações socioeconômicas, políticas e culturais, com o escopo de construçáo de um locus que distribui, pelo menos de forma aproximada os recursos necessários à fruição dos direitos sociais nesse território, como fonte de realização de vida e como pressuposto do desenvolvimento como direito fundamental humano, estabelece-se a conexão entre o $\mathrm{DaD}$ e $\mathrm{DdD}$ quanto ao mencionado direito urbano.

8 Conforme previstas na Declaração sobre o Direito ao Desenvolvimento da ONU. 
É no contexto urbano que se pode configurar concretamente o Direito ao Desenvolvimento, lugar onde se entrelaçam as interaçôes relacionais entre Estado (em sentido amplo), mercado e indivíduos, a se direcionarem (por ideal) à consecução dos DESC. É, portanto, na cidade que o indivíduo transcende como sujeito de direitos e passa a interagir com os demais atores sociais, demandando reivindicaçóes coletivas e igualdade de oportunidades de acesso aos recursos básicos pressupostos do desenvolvimento, a exemplo de educação, saúde, alimentação, habitação, emprego e distribuição de renda, fundamentados no respeito aos direitos humanos e nas liberdades fundamentais. Assim, o $\mathrm{DaD}$, no contexto do Direito à Cidade, pode assumir vertentes de desenvolvimento, posto que os espaços urbanos são dotados de peculiaridades sociais, econômicas, políticas e culturais que, por meio de estudos instrumentais, serviráo de base para a implementação de políticas públicas de desenvolvimento.

Expostas as relaçóes entre $\mathrm{DaC}, \mathrm{DaD}$ e $\mathrm{DdD}$ e a categorizaçáo dos mesmos, inequivocamente, como direitos humanos, surge o segundo nível de discussão com relação à efetividade desses direitos humanos e as teorias de universalismo e relativismo cultural. A questão que se póe é: sendo o $\mathrm{DaC}$ um direito humano ao desenvolvimento resultante de pactos e declaraçóes provenientes da Declaração dos Direitos do Homem, qual a relaçấo desse direito com as teorias universalista e realista? Qual se aplicaria ao $\mathrm{DaC}$ ? A Universalista? Ou ao contrário, a sua previsão como direito universal feriria as peculiaridades culturais de cada sociedade/País, devendo-se aplicar a teoria relativista? Ou, em uma terceira opção, a questáo estaria mais vinculada à própria efetividade do direito e não ao direito em si.

\section{Direito à Cidade e Direito ao Desenvolvimento: Direitos Universais, Rela- tivos ou Questão de Efetivação?}

Após as explanaçóes acerca do Direito à Cidade e sua interface com o Direito ao e do Desenvolvimento ( $\mathrm{DaD}$ e $\mathrm{DdD})$, necessário se faz, como ato preparatório à análise das relaçôes das teorias do universalismo e relativismo cultural em face do $\mathrm{DaC}$ e $\mathrm{DaD}$, empreender um estudo conceitual acerca dos direitos fundamentais humanos, notadamente suas características e atributos.

\subsection{DaC E DaD como Direitos Humanos Fundamentais: Atributos}

Consoante exposto, o Direito à Cidade é um direito humano dentro da categoria de Direito ao Desenvolvimento, que, por sua vez, emana da Declaraçáo dos Direitos do Homem e, portanto, é um direito fundamental humano com as mesmas características que essa categoria de direitos, as quais passamos a analisar. 
Os direitos fundamentais humanos (inclusos o $\mathrm{DaC}$ e $\mathrm{DaD}$ ), em sua essência, possuem como características a historicidade, universalidade, essencialidade, imprescritibilidade, inalienabilidade, irrenunciabilidade, inviolabilidade, efetividade, limitabilidade ou relatividade e integralidade ou unidade. Segundo Flávia Piovesan ${ }^{9}$, a historicidade dos direitos humanos é fruto de uma construção a partir de fatos históricos emblemáticos na violação de direitos, a exemplo, prioritariamente, do Pós-Guerra, como uma reação às atrocidades praticadas, inclusive sob o manto do liberalismo/legalismo protagonizado pelo próprio Estado. Esse fato e outros posteriores de extremas violaçóes ensejaram a reconstrução do arcabouço de direitos humanos pautado em um valor supremo, qual seja, a dignidade da pessoa humana ${ }^{10}$, como paradigma e referencial ético orientador da ordem internacional, e em uma veemente reação e resistência à descartabilidade humana, conforme a autora ${ }^{11}$. A construção histórica desses direitos trouxe uma concepção contemporânea de direitos humanos, marcada pela universalidade e indivisibilidade.

A universalidade é claramente expressa desde a Carta das Naçóes Unidas de $1945^{12}$, quando prevê, em seu art. 55, "o respeito universal e a observância dos direitos humanos e liberdades fundamentais para todos, sem distinção de raça, sexo, língua ou religião". A Declaração Universal dos Direitos Humanos de 1948 veio, posteriormente, a elencar detalhadamente quais seriam tais direitos, fixando, assim, uma espécie de "código comum e universal de direitos humanos"13, como uma obrigação legal no sentido de promovê-los. Esse código de direitos ${ }^{14}$ consagra em sua base uma plêiade de valores universais que

9 PIOvesan, Flávia. Direito ao desenvolvimento. II Colóquio Internacional de Direitos Humanos. São Paulo, 2002, p. 2.

10 Acerca da dignidade da pessoa humana, importante liçâao de Ingo Wolfgang Sarlet: "Nesse contexto, verifica-se ser de tal forma indissociável a relação entre a dignidade da pessoa e os direitos fundamentais que mesmo nas ordens normativas onde a dignidade ainda não mereceu referência expressa, não se poderá - apenas a partir deste dado - concluir que não se faça presente, na condição de valor informador de toda a ordem jurídica, desde que nesta estejam reconhecidos e assegurados direitos fundamentais inerentes à pessoa humana. [...] /em suma, o que se pretende sustentar de modo mais enfático é que a dignidade da pessoa humana, na condição de valor (e princípio normativo) fundamental que 'atrai o conteúdo de todos os direitos fundamentais', exige e pressupóe o reconhecimento e proteçáo dos direitos fundamentais de todas as dimensôes. Ver sarlet, Ingo Wolfgang. Dignidade da pessoa humana e direitos fundamentais na Constituiçáo Federal de 1988. Porto Alegre: Livraria do Advogado, 2006, p. 84.

11 piovesan, Flávia. Direitos humanos e o direito constitucional internacional. 14 ed. São Paulo: Saraiva, 2013, p. 192.

12 OnU. Carta das Naçóes Unidas. EUA: São Francisco, 1945. Disponível em: http://nacoesunidas.org/ carta. Acesso em 31 jan 2015.

13 Idem n. 11, p. 200.

14 Flávia Piovesan, ao discorrer sobre o sistema internacional de proteção dos direitos humanos, afirma com bastante propriedade, que a plêiade de instrumentos jurídicos (pactos, tratados e declaraçôes) formam um todo integrado de proteção universal: "Esse processo de "juridicização" da Declaração começou em 1949 e foi concluído apenas em 1966, com a elaboraçáo de dois tratados internacionais distintos - o Pacto Internacional dos Direitos Civis e Políticos e o Pacto Internacional dos Direitos 
devem ser seguidos e promovidos pelos Estados, aos quais EDUARDO MUYLAERT ANTUNES ${ }^{15}$ chama de "ética universal". RENÉ CASSIN ${ }^{16}$ confirma a universalidade ao reafirmar que o elenco de direitos contidos na Declaração de 1948 se aplica a "todas as pessoas de todos os países, raças, religióes e sexos, seja qual for o regime político dos territórios nos quais incide".

A universalidade coliga-se com a essencialidade, dado que o código de direitos baseia-se na imprescindibilidade da necessária condição de dignidade da pessoa humana como valor básico e universal, a qual conduz a uma indivisibilidade dos direitos, quando foi previsto pela Declaração de 1948, simultaneamente, os direitos civis e políticos e os direitos sociais, econômicos e culturais, os quais, segundo Flávia Piovesan (2013, P. 206), terminaram por associar os ideais e filosofias liberais e sociais da cidadania, ao vincular liberdade e igualdade, antes dissociadas e limitadas a direitos de liberdade, segurança e propriedade.

Esse contexto se aplica adequadamente à problemática das cidades associada aos processos de urbanização sob a influência do neoliberalismo e, portanto, de uma individualidade extrema com base no poder aquisitivo, que termina por trazer uma fissura na equitatividade e qualitatividade da distribuiçáo dos DESC no espaço urbano, demandando, assim, uma intervenção estatal no sentido da garantia do Direito à Cidade, nos exatos termos da principiologia da própria Carta da ONU, que impóe aos Estados o dever de prever, garantir e efetivar tais direitos por meio de plano de açóes (PIOVESAN, 2013, p. 206).

Econômicos, Sociais e Culturais - que passaram a incorporar os direitos constantes da Declaraçáo Universal [dentro os quais se insere o $\mathrm{DaC}$ e o $\mathrm{DaD}$ ]. Ao transformar os dispositivos da Declaraçáo em previsôes juridicamente vinculantes e obrigatórias, os dois pactos internacionais constituem referência necessária para o exame do regime normativo de proteçáo internacional dos direitos humanos. [...] A partir da elaboração desses pactos se forma a Carta Internacional dos Direitos Humanos, International Bill of Rights, integrada pela Declaração Universal de 1948 e pelos dois pactos internacionais de 1966. violação dos direitos das crianças, entre outras formas específicas de violação. [...] Diversamente dos tratados internacionais tradicionais, os tratados internacionais de direitos humanos não objetivam estabelecer o equilíbrio de interesses entre os Estados, mas sim garantir o exercício de direitos e liberdades fundamentais aos indivíduos. [...] Atente-se que o Direito Internacional dos Direitos Humanos, com seus inúmeros instrumentos, não pretende substituir o sistema nacional. Ao revés, situase como direito subsidiário e suplementar ao direito nacional, no sentido de permitir sejam superadas suas omissóes e deficiências. No sistema internacional de proteçáo dos direitos humanos, o Estado tem a responsabilidade primária pela proteçấo desses direitos, ao passo que a comunidade internacional tem a responsabilidade subsidiária. [...] Os tratados de proteção dos direitos humanos consagram, ademais, parâmetros protetivos mínimos, cabendo ao Estado, em sua ordem doméstica, estar além de tais parâmetros, mas jamais aquém deles. (acréscimo nosso).

15 antunes, Eduardo Muylaert. A natureza jurídica da Declaraçáo dos Direitos Humanos. São Paulo: Revista dos Tribunais, n. 446, 1972, p. 35

16 CASSIN, René. El problema de la realización de los derechos humanos em la sociedade universal. In: Veinte ańos de evolutión de los derechos humanos. Pamplona: Universidade Nacional Autónoma de México, 1974, 397. 
$\mathrm{Na}$ sequência, a imprescritibilidade, pela qual tais direitos náo decaem com o decurso do tempo; a inalienabilidade, pela qual é inviável a transferência dos direitos; a irrenunciabilidade, pela qual tais direitos não podem ser renunciados e ninguém pode abrir mão dos mesmos; a inviolabilidade, que impede a violação desses direitos, nem mesmo por leis infraconstitucionais ou atos administrativos, sujeitando seus infratores às penas de responsabilidade civil e criminal; a integralidade ou unidade, em que tais direitos compóem uma unidade interdependente e indivisível, não sendo possível a fruição de um sem o outro, o que enseja a teoria das dimensóes de direitos humanos fundamentais, pela qual não há a sobreposição ou substituição de uma geração por outro, mas um acúmulo de proteção e garantias (SARLET, 2006, p. 93) ${ }^{17}$; todos esses são características dos direitos humanos, mas que têm o condão de inibir ou mesmo blindar qualquer possibilidade de violação ou desprezo dos mesmos por quem quer que seja, inclusive o próprio indivíduo.

Por fim, de importância fundamental para a discussão central da temática deste item, os direitos humanos são dotados de efetividade e relatividade. Pela primeira, resta para o Poder Público ou Estado o ônus de criar mecanismos e planos de ação para a concretização ou efetivação desses direitos. Do contrário, os direitos humanos cairiam no manto da mera formalidade. A relatividade, por sua vez, ponto de alta relevância na discussão proposta, é característica que exclui aos direitos humanos o atributo de absolutos, não obstante sejam universais. Essa premissa é essencial para a exata compreensão desses direitos, notadamente quando em relação dialética com contextos culturais nos quais serão aplicados. Disso resulta que o elenco dos direitos na Declaração de 1948 e demais instrumentos (Pactos e Declaraçóes posteriores) traz a ideia de universalidade inequivocamente, em nossa compreensão. São direitos universais, porque, como dito, aplicam-se, indistintamente a toda e qualquer pessoa independentemente de qualquer elemento de discrímen.

A universalidade, assim, é atributo dos direitos materiais humanos, em sua essência, in abstrato. Entender contrariamente, a despeito de todo arcabouço histórico de violaçóes que os ensejou, seria equivalente a institucionalizar uma lacuna jurídica que os sujeitasse a possíveis violaçóes. Considerando que a universalidade se coliga, indissociavelmente, com a dignidade da pessoa humana, não há como refutar a ideia de que tais direitos, materialmente falando, sejam relativos a qualquer pessoa, independentemente de seu contexto político, social e cultural. Isso significa dizer que a universalidade dos direitos humanos (nos quais se insere os direitos à cidade e ao desenvolvimento) se relaciona, a nosso sentir,

17 No mesmo sentido, Flávia Piovesan (2013, p. 232) detalha: "A partir desse critério, os direitos de primeira geração correspondem aos direitos civis e políticos, que traduzem o valor da liberdade; os direitos de segunda geração correspondem aos direitos sociais, econômicos e culturais, que traduzem, por sua vez, o valor da igualdade; já os direitos de terceira geração correspondem ao direito ao desenvolvimento, direito à paz, à livre determinação, traduzindo o valor da solidariedade”. 
especificamente com a natureza material dos mesmos. Porém, apesar de serem direitos universais, os mesmos não são absolutos, posto que dotados de relatividade.

Como conciliar tais atributos? A nossa compreensão reside no fato de que a relatividade dos direitos humanos se situa no campo da efetividade dos mesmos e não de sua previsão material.

Assim, os direitos humanos, quando em conjunturas de crise ou em colisão com outros interesses/direitos humanos, sofrerão, necessariamente, uma restrição em sua aplicação ou efetividade, através da aplicação de um juízo de ponderação ${ }^{18}$. Considerando que os direitos humanos fundamentais, por excelência, baseiam-se em, como dito, uma ética universal (CASsIN, 1974, p. 397), ou seja, em valores ${ }^{19}$ e princípios axiológicos, a sua efetivação ou aplicação não pode ser procedimentalizada através do critério do "tudo ou nada", fundamentando apenas na vigência das normas (regras ou leis), afastando-se do positivismo jurídico que possibilitou, inclusive, as atrocidades da Grande Guerra (villey, 2007, p. 3-4 $)^{20}$. Ao contrário, sua efetividade se dá por meio de juízo de valor, de peso, de ponderação (baseado em um senso de justiça), mormente quando há colisão de interesses ou direitos, nos quais se deve utilizar, para a soluçáo do caso, métodos de razoabilidade, adequação, necessidade, ensejando uma relativização de um direito em detrimento de

18 Sobre esse método, Humberto Ávilla traz relevante ensinamento: "A ponderação de bens [jurídicos como os direitos] consiste num método destinado a atribuir pesos a elementos que se entrelaçam, sem referência a pontos de vista materiais que orientem esse sopesamento. [...] É preciso estruturar a ponderaçáo com a inserção de critérios. Isso fica evidente quando se verifica que os estudos sobre a ponderaçáo invariavelmente procuram estruturar a ponderação com os postulados de razoabilidade e de proporcionalidade e direcionar a ponderação mediante utilização dos princípios constitucionais fundamentais [dignidade da pessoa humana]". Ver Ávilla, Humberto. Teoria dos princípios: da definição à aplicação dos princípios jurídicos. Sáo Paulo: Malheiros Editores, 2009, p. 145. Sobre o mesmo tema, Luís Roberto Barroso afirma que "[a ponderação] consistem em uma técnica de decisão jurídica, aplicável a casos difíceis, em relação aos quais a subsunção se mostrou insuficiente. A insuficiência se deve ao fato de existirem normas de mesma hierarquia indicando soluçóes diferenciadas". Ver barroso, Luís Roberto. Curso de direito constitucional contemporâneo: os conceitos fundamentais e a construção do novo modelo. São Paulo: Saraiva, 2011, p. 358.

19 Sobre valores e moral, segue lição de Enoque Feitosa, que revela a densidade e volatilidade do tema: "Por outro lado - e isso permite distinguir as críticas de MARx feitas ao padrão moral positivo, daquelas observações que ele faz e que constitui uma ética normativa - há que se diferenciarem numa sociedade duas moralidades: uma comum e difusa resultante do sistema econômico e de relaçóes historicamente existentes e outra na forma de incipiente ética superior e que é projeção de um mundo em gestação nas entranhas da própria sociedade atual e que poderá vir a ser, a depender dos esforços individuais e coletivos, o sistema que poderá vir a se instaurar como nova moralidade de um agrupamento dado. Ver: feitosa, Enoque. De como o marxismo lida com a relação entre prescrição e descrição do mundo e as demandas por sua transformação. Encontro internacional do GT Ética e Cidadania da ANPOF. Pernambuco: UFPE, 2013.

20 Michel Villey, discorrendo sobre o assunto, afirma que o positivismo jurídico (no período anterior às Declaraçóes de Direitos Humanos) era base jurídica dos Estados fechada em leis, mas submetida às "vontades arbitrárias dos poderes públicos". Foi-lhe necessário um "antídoto": os direitos humanos, oriundos da Escola do Direito Natural, baseados em arcabouços éticos e de justiça. Ver villey, Michel. O direito e os direitos humanos. São Paulo: WMF Martins Fontes, 2007, p. 3. 
outro, porém não configurando a relativização do próprio direito, mas a sua adequada aplicação aos casos e situaçóes concretas (DWORKIn, 2002, p. 39 e 44-45).

É de se realçar mais ainda que a natureza jurídica dos direitos elencados nas Declaraçóes de Direitos Humanos (demais instrumentos sequenciados a ela e que preveem outros direitos) não é simplesmente de norma estrita ou leis, mas de princípios axiológicos que inspiram a enunciação de direitos que só passam à categoria de leis quando do processo de ratificação e incorporação nos ordenamentos nacionais. Ainda assim, é cediço que, pela densidade valorativa que lhes inspira, em face do princípio da dignidade da pessoa humana, este, por sua vez, seria o fio condutor de todos os direitos que lhe descendem, de maneira a terem uma posição de supremacia ao ponto de, em não poucas constituiçóes, serem reputados como impassíveis de modificação por emendas constitucionais, consubstanciando as cláusulas pétreas.

De maneira que, à guisa de conclusão, o Direito à Cidade contextualizado no Direito ao Desenvolvimento, como direitos humanos fundamentais que são, revestem-se de caráter universal, inalienável, irrenunciável, inviolável, imprescritível, integrante, por sua vez, de um rol de outros direitos que com ele formam um arcabouço interdependente de fruição. É, ainda, efetível a partir de açóes do Estado à sua concretização, todavia, nesse mister, reveste-se de relatividade quando, em face de conjunturas sócio-políticas e culturais que ensejam colisão de direitos humanos, poderá ser limitado ou ponderado em sua extensão, contudo realizável a toda e qualquer pessoa. Essa relatividade é fundamental, notadamente, em face da existência de duas teorias que analisam a concepção dos direitos fundamentais humanos sob a ótica do contexto social, político, econômico, cultural e moral em que se inserem: universalismo e relativismo cultural.

\subsection{Universalismo e Relativismo Culturais e o Direito à Cidade: Um Problema de Concepção ou de Efetividade?}

O universalismo cultural se consubstancia, na verdade, em uma teoria ou movimento que, conforme já demonstrado, defende a ideia de que os direitos humanos fundamentais têm, em face de seu fundamento na dignidade da pessoa humana, uma aplicação universal a qualquer pessoa de qualquer sociedade, independentemente do sistema social, econômico, político, cultural e moral em que se insere. A essência dessa corrente está na individualidade ou singularidade da pessoa. Opóe-se a esse movimento universal a teoria do relativismo cultural, e o cerne desse embate se concentra no alcance ou extensão que os direitos humanos admitem, notadamente pela concepção contemporânea (ao mínimo, ocidental) que esses direitos imprimiram nos ordenamentos jurídico-constitucionais no sentido de uma remodelação de sua soberania em atenção ao complexo de direitos que se entendeu mínimos, os quais os Estados-nações devem garantir e promover, sob pena de ingerência internacional em caso de violação (PIOvesan, 2013, p. 211). Ao passo que os 
universalistas defendem a ampla extensão e aplicação desses direitos em qualquer espaço e conjuntura e a qualquer pessoa, os relativistas submetem-nos ao sistema político, social, econômico, cultural e moral de dada sociedade. Saliente-se que a linha argumentativa dos relativistas parece se centrar na própria noção de direito em sinergia com seu contexto político, cultural, social e moral.

Sob esse prisma, cada cultura possui seu próprio discurso acerca dos direitos fundamentais, que está relacionado às específicas circunstâncias culturais e históricas de cada sociedade. Nesse sentido, acreditam os relativistas, o pluralismo cultural impede a formação de uma moral universal, tornando-se necessário que se respeitem as diferenças culturais apresentadas por cada sociedade, bem como seu peculiar sistema moral (PIOVESAN, 2013, p. 211).

Aprofundando a questão, a discussão passa necessariamente pela concepção acerca do homem em relação à sociedade. Para os relativistas, o direito toma como a base a perspectiva do grupo, da coletividade, e a relação do indivíduo em relação a este, de maneira que o diagnóstico de uma possível violação de direitos humanos necessariamente perpassará pela repercussão do ato sobre dada pessoa quanto à coletividade em que se insere. R. J. VINCENT $(2005$, p. 8) afirma que o relativismo advoga o entendimento de que a noção ou as regras de moral variam de acordo com o espaço e o contexto sociocultural, de maneira que não haveria uma "moral universal". Ainda segundo o autor, há um DEscompasso e uma tensão entre a compreensão de moral pelos realistas e a agenda internacional, que, a nosso entender, capitanearia a teoria universalista.

Esse entendimento é fortalecido ainda mais por uma distinção comum entre os realistas; o comportamento do grupo (coletividade) versus o comportamento individual, ou a moral pública versus a moral individual (VINCENT, 2005, p. 8). (tradução nossa).

Boaventura de Sousa Santos (2007, p. 22-23), a favor do relativismo cultural, afirma que o "imperialismo cultural e epistemicídio são parte da trajetória histórica da modernidade ocidental", a entender por prejudicial e reprovável a visão etnocêntrica ocidental. Com base nisso, o autor propóe um procedimento "hermenêutico diatópico", baseado na comparação e dialética entre duas culturas. Nesse processo, está a proposta de um multiculturalismo emancipatório.

Compete à hermenêutica diatópica proposta neste artigo transformá-los [os direitos humanos] numa política cosmopolita que ligue em rede línguas nativas de emancipação, tornando-as mutuamente inteligíveis e traduzíveis (santos, 2007, p. 30). (acréscimo nosso).

Observa-se que a questão crucial que envolve o realismo versa acerca da cultura e, nesta, a concepção de moral como requisito de validade. Em vista disso, JACK DONNELlY 
(2005, p. 7) discorre sobre várias correntes de realismo, que vão desde tendências fortes ou radicais, que consideram a cultura como única fonte de validade do direito, até movimentos mais amenos, que entendem a cultura como possibilidade de fonte de validade da norma entre outras. À guisa de dirimir as divergências, ao mesmo do ponto de vista desse artigo e de nossa proposta, JACK DONNELLY, R. J. VINCENT E FLÁVIA PIOVESAN reagem contrária e veementemente ao relativismo e favoravelmente ao universalismo jurídico. São unânimes ao reafirmarem a universalidade dos direitos humanos, reforçando que esses mesmos direitos garantem o livre exercício da cultura e a autodeterminação dos povos, desde que tais não sejam fundamentos ou pretextos para a violação de direitos humanos e para se imiscuir do monitoramento da comunidade internacional. Há um "mínimo ético irredutível" (PIOVESAN, 2013, p. 212-213) intangível sob pena de agressão à dignidade da pessoa humana.

A Declaração de Viena de $1993^{21}$, em face de tais divergências e discussóes, em seu $\$ 5^{\circ}$, tratou de demarcar o posicionamento de seus signatários, reafirmando a universalidade dos direitos humanos, que devem ser tratados de forma global, justa e equitativa, não desprezando ou menosprezado as peculiaridades culturais e religiosas a nível regional e nacional, desde que assumam e persigam seu dever de promover todos os direitos humanos. Nesse sentido, JACK Donnelly (2005, p. 7-8), posiciona-se contrariamente ao relativismo, afirmando que as divergências são, de certa forma, equivocadas, porque há confusão entre direitos humanos, como direitos simplesmente do homem, com conceitos mais amplos de dignidade e justiça social, que, embora inspirem os direitos, não são os próprios direitos. Afirma, ainda, que não obstante a sua importância, a cultura "não é um destino", e, portanto, não poderia figurar como parâmetro ou fonte única de validade de uma norma.

[A cultura] é dinâmica e contestável, mudando constantemente através de conflitos, muitas vezes violentos de controle sobre significados sociais. Tenho argumentado (2003, cap. 4) que os direitos humanos têm uma estrutura em vez de uma base cultural: eles respondem às ameaças distintas à dignidade humana e às oportunidades sociais e políticas específicas criadas pelos mercados modernos e Modernos estados. A universalidade dos direitos humanos é, portanto, funcional e historicamente contingente. Os mercados e os estados têm penetrado praticamente todo o globo e engenho humano (pelo menos até agora) mostrou-se incapaz de elaborar respostas mais eficazes (DONNELLY, 2005, p. 8). (tradução nossa) (grifo nosso).

21 Onu. Declaração e Programa de Ação de Viena. Viena, 1993. Disponível em: www.oas.org.br. Acesso em 31 jan 2015. 
Por seu turno, R. J. Vincent (2005, p. 36) firma taxativamente seu entendimento pela universalidade dos direitos humanos, contudo propóe uma espécie de categoria, qual seja, a de direitos humanos relativamente universais, dispensando o devido valor às concepçóes morais e culturais, que, por sua vez, são absolutamente compatíveis com a concepção histórica de direitos humanos contida na Declaração de Direitos Humanos e demais instrumentos.

Meu principal objetivo é explicitar e defender os direitos humanos como direitos universais. Eu não sustento, contudo, que esses direitos sejam estáticos, imodificáveis ou absolutos; qualquer elenco ou concepção de direitos humanos — e a ideia de direitos humanos por si mesma — apresenta uma especificidade cultural e contingente. (...) Este livro demonstra que a contingência histórica e a particularidade de direitos humanos é completamente compatível com a concepção de direitos humanos como direitos morais universais, que não nos permite aceitar fortes reivindicaçôes do relativismo cultural (VINCENT, 1984, p. 419).

Expostas teorias do universalismo e relativismo culturais, mister se faz contextualizá -los, inclusive em face do Direito à Cidade objeto desse artigo. Parte-se, em uma primeira instância, dos próprios conceitos e atributos de direitos fundamentais humanos conforme discorridos no item 3.1, nos quais se insere o $\mathrm{DaC}$. A partir daí, passa-se à proposição de que, não obstante a ideia de R. J. VINCENT de um universalismo relativo, bem como o maciço reconhecimento da relevância dos valores éticos, morais e culturais, a questáo do universalismo coliga-se necessariamente aos direitos humanos materiais, sua simples previsão, enquanto que a questáo do relativismo estaria vinculada ao atributo da efetividade dos direitos humanos, ou seja, à sua aplicação, que por sua vez, importaria necessariamente em juízo de ponderação acerca de um dado direito em face de um dado universo ou contexto de direitos de fundo relevantemente moral, político, cultural e social (conflito de direitos humanos), todavia sem subtrair a validade do direito, mas, possivelmente impingindo-lhe certa gradação em face desses últimos. Isso significa dizer que a lista dos Direitos Humanos são um rol in abstrato, que serão concretizados e efetivados a partir da realidade socioeconômica, cultural e política de cada País, em relaçáo, muitas vezes de conflito com direitos dessa ordem ou de uma necessidade de adequação, mas que impedem a irrefutável observância desses direitos universais em decorrência até da auto -aplicabilidade que lhes é própria, dando-lhes, assim a devida gradação no caso concreto através de critérios de ponderação, razoabilidade e adequação.

Assim, a negativa de validade do universalismo atingiria o próprio direito, enquanto previsão ou abstração, e sua essência: a dignidade da pessoa humana. Daí porque o rol de direitos humanos é absoluto, indivisível e teleologicamente plausível, pois é fruto de uma gênese histórica de construção cujo objetivo é evitar veementemente novas violaçôes e atrocidades como outrora, inclusive sob os auspícios do positivismo jurídico ou em 
virtude de qualquer que seja a unidade de argumentação que destoe do valor fundamental e supremo humano: a dignidade. $\mathrm{O}$ relativismo, por outro lado, é condição de máxima efetividade ou concretização ao direito, considerando-se que os direitos humanos são relativos quando em rota de conflito com outros de sua categoria, caso em que haverá, como explanado, a necessidade de exercício de um juízo de ponderação como método procedimental de solução de conflitos ou mesmo de adequação à realidade peculiar, que importará na limitação de um em face do outro direito. Segue-se uma quadro ilustrativo e representativo da proposição.

\section{Figura 1 - Universalismo de Efetividade Ponderada ou Relativa}

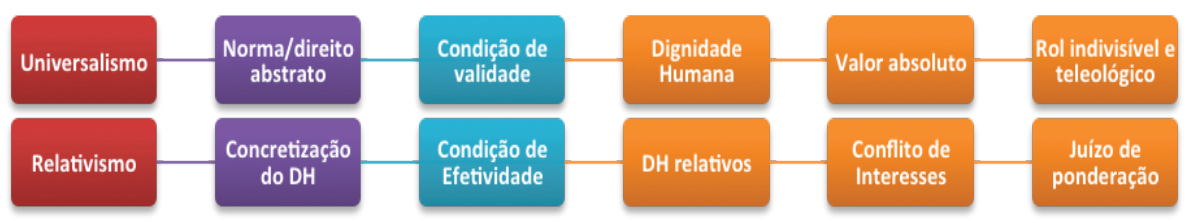

Do exposto, a universalidade desses direitos alcança quaisquer tipos de suas categorias: direitos civis, políticos, econômicos, sociais e culturais, e toda a gama de outros direitos fundamentais consubstanciados em Acordos, Pactos, Convençóes e Declaraçóes que tratem, inclusive, sobre categorias específicas de pessoas. Nesse universo se insere, claramente, o Direito à Cidade como uma vertente do Direito ao Desenvolvimento. Porém, é imperioso que os casos que podem incidir o relativismo cultural orbitam, quase que em sua totalidade, em torno de direitos que envolvem liberdades religiosa e cultural dotadas de certo grau de peculiaridade, como é o caso das culturas islâmicas e budistas próprias de sociedades orientais. A propósito, a título de reforço dessa premissa, os exemplos trazidos na doutrina dos mais tarimbados autores na área de Direitos Humanos versam todos sobre esses direitos específicos. Em via inversa, é extremamente dificultoso vislumbrar uma relatividade cultural (na forma como defendida pelos relativistas radicais) na previsão in abstrato de direitos civis e políticos, ou econômicos, sociais e culturais, a ponto de lhes retirar a condição de garantia, como seria o Direito à Cidade, objeto desse artigo. Quando se reporta a direitos dessa área $(\mathrm{DaC})$, pode-se listar: alimentação, habitação, saúde, seguridade social, lazer, vestuário, trabalho, todos, portanto, realizáveis no contexto da cidade. É nessa interface que o Direito à Cidade se situa e, tendo em vista a sua essencialidade e instrumentalidade ao Direito ao Desenvolvimento, notadamente quanto a imbuir a pessoa dos aspectos necessários e indispensáveis à condição de cidadão ${ }^{22}$, entende-se que

22 A respeito de uma concepção rigorosa de cidadania, no seu sentido técnico-jurídico, Fredys SorTo traz importante liçáo cotejando esse instituto com o da nacionalidade com quem interage e que tem vínculo direto com a temática deste artigo: "A nacionalidade, ensina Aláez Corral (2006, p. 6). É ‘[...] o vínculo 
não se trata, assim, de um direito relativo culturalmente, mas a sua garantia, à semelhança dos demais componentes do rol de direitos humanos, deve ser promovida independentemente do contexto socioeconômico, cultural, político e moral de cada País, embora seja plenamente viável a possibilidade de adequaçóes que poderáo variar segundo alguns padróes ou modelos de urbanização (por exemplo), mas nunca no sentido de expurgar o Estado de tal responsabilidade, a ponto de relegar seus cidadãos a uma situação de vulnerabilidade social extrema.

Nesse sentido, os padrões de urbanização atuais, segundo a influência severa da globalização, neoliberalismo e capitalismo, terminaram por ensejar sérios problemas quanto aos elementos que compóem o $\mathrm{DaC}$ e que são causas de aviltantes desestruturas sociais no contexto urbano, a exemplo da marginalização, miséria, desabrigados, deficiência intelectual e profissional, precarização da saúde e, como consequência, uma fragilidade brutal na concepção e exercício da cidadania ${ }^{23}$. No contexto do Direito à cidade, o processo

legal que une o indivíduo a um ordenamento jurídico soberano, integrando-o no coletivo estável e permanente de súditos'”. [...] A cidadania, diz o mesmo autor (2006, p. 6), '[...] se deve conceber como uma pluralidade de situaçôes jurídicas através das o ordenamento permite a integraçấo indivíduo nas diversas esferas da comunicação social, juridicamente reguladas". Ver sorto, Fredys Orlando. Cidadania e nacionalidade: institutos jurídicos de direito interno e de Direito Internacional. Verba Juris: Anuário da Pós-Grauaçấo em Direito, João Pessoa, ano 8, n. 8, p. 43, jan/dez. 2009. Por outro lado, tratando sobre a divergência do multiculturalismo em relação aos direitos humanos, Fredys Sorto faz relevante análise quanto a estes em face do cidadão: "Não se deve subestimar o tema do multiculturalismo, porque ele mantém intensa vinculaçáo com a problemática acima enunciada (obstáculos à efetivaçáo dos direitos humanos). [...] É óbvio que não se devem tolerar violaçōes de direitos já consagrados como normas de jus cogens na sociedade internacional, dado que os direitos com dignidade maior devem prevalecer sobre os de menor valor (conflito de interesses). [...] Na superaçáo dessa problemática certamente a educaçáo e o desenvolvimento têm papel de grande importância. A referência não é a qualquer tipo de educação, mas à Educaçấo que forma cidadãos comprometidos com a comunidade política à qual pertencem $\mathrm{e}$ igualmente comprometidos com os valores comuns da Humanidade". Ver sorto, Fredys Orlando. A Declaraçáo Universal dos Direitos Humanos no seu sexagésimo aniversário. Verba Juris: Anuário da Pós-Graduação em Direito, João Pessoa, ano 7, n. 7, p. 12-13, jan/dez. 2008.

23 Nesse sentido, Domenico Losurdo destaca o paradoxo do liberalismo (à semelhança do neoliberalismo) que proclamava a liberdade (para poucos) e violava a liberdade dos negros: "Sim, Calhoun fala da escravidão dos negros como um 'bem positivo', mas embora utilize uma linguagem altissonante, também o filósofo inglês, ao qual o autor estadunidense remete explicitamente, considera óbvia e natural a escravidão nas colônias e contribui pessoalmente para a formalização jurídica desse instituto na Carolina. Participa na redação da norma constitucional pela qual 'todo homem livre da Carolina deve ter absoluto poder e autoridade sobre os seus escravos negros seja qual for sua opiniāo e religião'. Ver losurdo. Domenico. Contra-história do liberalismo. São Paulo: Ideias e Letras, 2006, p. 15.

Em Hegel, Marx e a Tradição Liberal, Losurdo afirma que "a negação da questão social é ainda mais radical no publicismo neoliberal dos nossos dias, que, também nesta negaçáo, não por acaso, acaba por se encontrar com Nietzsche. [...] E Nietzsche, por sua vez, polemizando contra aqueles que de 'profundas injustiças' no ordenamento social, os acusa de ter 'imaginado responsabilidades e formas de vontade que não subsistem de modo algum. Não é lícito falar de uma injustiça nos casos em que não estáo presentes as condiçóes preliminares para a justiça e a injustiça'. Assim como em Nietzsche, o protesto social, longe de remeter a condiçóes objetivas e a uma real 'injustiça', remete, ao contrário, ao ressentiment, ao rancor que os fracassados da vida nutrem pelos melhores e mais afortunados, para Von Hayek, o que alimenta a 
de urbanização é marcado pela industrialização (sempre em expansão) e pelo regime de mercado capitalista. Este, por sua vez, tem como estratégia básica o reinvestimento ou a reaplicação de seus lucros, através do incentivo ao consumo constante (HARVEY, 2013), gerando um processo urbanístico impulsionado pelo capitalismo com capacidade potencial para alterar ou ditar estilos/modos de viver, posto ser o consumo o fio condutor das estratégias capitalistas. Há uma interação simbiótica entre esse regime de mercado e o consumidor, assim considerado o indivíduo/cidadão. Tais percepçóes são histórica e juridicamente verificadas, desembocando em uma dicotomia maléfica: aqueles que, com poder aquisitivo, adquirem os elementos de seu bem-estar social e de cidadania versus aqueles que, despidos de qualquer instrumentalidade aquisitiva, sobrevivem à base de um pálido modus vivendi urbano periférico e dependente, cada vez mais, de uma interferência estatal que lhes garanta tais direitos fundamentais (BAUMAN, 2009, p. 6). CANÇADO TRINDADE (2007, p. 421) discorre sobre a problemática abordando os desafios do Direito Internacional na proteção dos direitos humanos, cotejando, ao final, o tema com a questâo do relativismo cultural como mais um obstáculo a efetivação desses direitos.

Com efeito, a atual recessão econômica mundial veio agravar as disparidades já insuportáveis entre países industrializados e países em desenvolvimento, no plano internacional, e entre diferentes setores da sociedade, no plano interno. Lamentavelmente têm crescido, em distintos continentes, a humilhação do desemprego, assim como, de modo alarmante, a pobreza extrema. Em tempos de "globalizaçáo" da economia, as fronteiras passaram a se abrir à livre circulação dos capitais, inversóes, bens e serviços, mas náo necessariamente das pessoas, dos seres humanos. A crescente concentração de renda e poder em escala mundial, a acompanhar pari passu a chamada "globalização", em meio à glorificaçáo do mercado, passou a acarretar o trágico aumento - estatisticamente comprovado - dos marginalizados e excluídos em todas as partes do mundo, nesta mais recente manifestação de um perverso neodarwinismo social (TRINDADE, 2007, 421). (grifo nosso).

Destaque-se, nesse assunto, a realização da Cúpula Mundial para o Desenvolvimento Social em 1995 (TRINDADE, 207, p. 421-422), em Copenhagen, que tratou exatamente dessa temática sob o viés da redução de pobreza, incremento do emprego e integração social, todos exercíveis no contexto do $\mathrm{DaC}$, os quais demandam urgentemente o

exigência de 'justiça social' são 'sentimentos' absolutamente nada elevados, como 'o desprezo por pessoas que estão em melhor situação que nós ou simplesmente a inveja' e 'institutos predatórios'. A objetividade da questão é, assim, dissolvida na responsabilidade individual e até mesmo na psicologia individual dos que sofrem condição de miséria”. Essa opinião de Nietzsche e Hayek terminam por demonstrar a concepção desses liberais quanto à exclusão de responsabilidade do Estado na promoção dos hoje chamados DESC. Ver Losurdo, Domenico. Hegel, Marx e a tradiçáo liberal. São Paulo: Unesp, 1998, pp. 208-209. 
"renascimento dos ideais de justiça social" e um "desenvolvimento mundial da humanidade" para combater e tais problemas. Outro fato importante relatado como desafio à efetivação desses direitos é a negligência e fragilidade estatais em bem se postar nessa realidade global e capitalista sem se subsumir aos seus movimentos, bem como em proteger os hipossuficientes socioeconômicos sob sua jurisdição. Instrumentos de relevância nesse ponto são a Agenda Habitar I (à época. Atualmente, Habitat III) ${ }^{24}$ e a Declaração de Istambul ${ }^{25}$, frutos da II Conferência Mundial das Naçóes Unidas, e que versou sobre a precariedade de um bilhão de pessoas (à época) em condições de abandono, sem moradia e em condiçóes subumanas de vivência, o que se traduz em uma nova forma de exclusão e discriminação (TRINDADE, 2010, p. 424). A referência a essas dificuldades especificamente na área dos direitos socioeconômicos tem o condão de realçar os desafios para a efetividade dos direitos humanos, não só na área de direitos civis e políticos, mas, igualmente, na seara dos DESC. Por oportuno, é de se destacar que graves violaçóes de direitos humanos não se circunscrevem aos repugnantes fatos de genocídios, torturas e guerras, mas configuram, semelhantemente, violaçôes aos DESC a timidez e negligência estatais em bem desempenhar sua responsabilidade de efetivação de tais direitos para uma aproximação mais adequada de uma distributividade social (DOUZINAs, 2010) ${ }^{26}$, essencial à formação e robustecimento do cidadão. Acrescente-se, ainda, que, conforme bem preleciona AMARTYA SEN, sem a fruição dos DESC torna-se inviável o exercício dos direitos civis e políticos e de desenvolvimento plural, inclusive, das capacidades. Por consequência, tem-se uma parcela da sociedade hipossuficiente econômica e politicamente, incapaz de bem se postar entre o seu Estado e demais entidades na reivindicação de suas necessidades em uma perspectiva

24 onu. Agenda Habitat. Vancouver, 1976. Disponível em: http://nacoesunidas.org.br/agencia/habitat. Acesso em 31 jan 2015. Elementos chave a serem considerados na Habitat III para a criação de um padrão de crescimento urbano sustentável: a) Política urbana nacional: deve estabelecer uma conexão entre dinâmicas de urbanização e o processo marco de desenvolvimento nacional; b) Leis, instituiçóes e sistemas de governança: esses são os alicerces normativos para ação, os princípios operacionais, as estruturas organizacionais e as relaçóes institucionais e sociais que perpassam o processo de urbanizaçáo; c) Economia urbana: embora haja uma forte e positiva correlação entre crescimento econômico e urbanização, esse potencial relacionamento não é espontâneo e nem se desenvolve por si mesmo. HABITAT III poderá ser o meio para se colocar os pilares centrais para um robusto desenvolvimento econômico urbano.

25 ONU. Declaraçáo de Istambul sobre assentamentos humanos. Istambul, 1996. Disponível em: http:// pfdc.pgr.mpf.mp.br. Acesso em 31 jan 2015.

26 Sobre esse descompasso ou paradoxo entre elenco e efetividade dos direitos humanos, Douzinas desfere forte e relevante crítica: "Se o século XX é a era dos direitos humanos, seu triunfo é, no mínimo, um paradoxo. Nossa época tem testemunhado mais violaçôes de seus princípios do que qualquer uma das épocas anteriores e menos 'iluminadas'. O século XX é o século do massacre, do genocídio, da faxina étnica, a era do Holocausto. Em nenhuma outra época da história houve um hiato maior entre os pobres e os ricos do mundo ocidental, e entre o Norte e o Sul globalmente. 'Nenhum progresso permite ignorar que nunca, em número absoluto, nunca tantos homens, mulheres e crianças foram subjugados, passaram fome e foram exterminados sobre a terra. Ver douzinas, C. O fim dos direitos humanos. São Leopoldo: Unisinos, 2009. 
coletiva (SEN, 2010, p. 10), além de engrossar as fileiras da degeneração e miséria sociais tâo antagônicas à ideia de dignidade humana, desenvolvimento e sustentabilidade urbana como direitos humanos fundamentais. Para além de reforçar a necessidade de efetividades dos DESC, os desafios arrolados exemplificativamente também têm o fulcro de sedimentar a perspectiva UNIVERSAL desses direitos, no tocante à sua previsão abstrata, dado que a possibilidade de sua relatividade (dentro da perspectiva radical) ensejaria desestrutura, desequilíbrio e violaçóes sociais tão aviltantes e de tal monta (para além da conjuntura atual) que não se poderia mensurar a sua dimensão, notadamente pela possibilidade de isenção de responsabilidades a que os Estados poderiam incorrer.

Pelo exposto, reafirme-se a condição de universal do Direito à Cidade e ao Desenvolvimento, como direitos humanos que são, dado que fundamentados no primado supremo da dignidade, e cuja relatividade se vincula à sua efetivação no campo da adequação à realidade socioeconômica de cada País. São, por assim dizer, direitos materiais humanos, instrumentais da cidadania, universalmente tutelados e relativamente aplicados em consonância às peculiaridades conjunturais de dada sociedade. Propóe-se, assim, aos direitos humanos, e ao Dac e DaD em especial, a Teoria do Universalismo de Efetividade ou Ponderada Relativa ${ }^{27}$. Especialmente quanto a esses DESC, JACK DONNELLY, acertadamente, posiciona-se pelo universalismo:

Finalmente, os direitos econômicos e sociais reconhecidos nos artigos 22 a 27 garantem, como direitos individuais, proteçôes básicas que em uma sociedade tradicional comumente são providas pela família ou pela comunidade como um todo: seguridade social, trabalho, DEscanso e lazer, subsistência, educação e participação na vida cultural da comunidade [todos exercíveis no contexto da cidade, urbano]. Mas náo são esses direitos os únicos a serem dirigidos novamente ao estado moderno, eles são mantidos simplesmente pelos indivíduos como pessoas humanas, e assim correspondem à individualização da pessoa na sociedade moderna. E o artigo 28, que garante uma ordem social e internacional em que os

27 Nesse sentido, ver trecho do discurso do Secretário-Geral da ONU à época, na sessão de abertura da Conferência de Viena, em 1993, que reforça a ideia de universalidade quanto à guarida e promoçáo desses direitos: "Que cada um de nós venha de diferentes culturas não absolve nenhum de nós da obrigação de cumprir a Declaração Universal. Tortura, estupro, antissemitismo, detenção arbitrária, limpeza étnica e desaparecimentos políticos — nenhum destes atos é tolerado por qualquer crença, credo ou cultura que respeita a humanidade. Nem mesmo podem ser eles justificados como demandas de um desenvolvimento econômico ou expediente político. Nós respeitamos as características religiosas, sociais e culturais que fazem cada país único. Mas nós não podemos deixar com que o relativismo cultural se transforme em refúgio para a repressão. Os princípios universais da Declaração da ONU colocam os indivíduos em primeiro lugar. Nós rejeitamos qualquer tentativa de qualquer Estado de relegar seus cidadãos a um status menor de dignidade humana. Não há contradição entre os princípios universais da Declaração da ONU e as culturas que enriquecem a comunidade internacional. O abismo real repousa entre as cínicas escusas de regimes opressivos e a sincera aspiração de seu povo". 
direitos previamente listados podem ser realizados, claramente reflete a peculiar noção moderna de responsabilidade internacional pela proteção e provisão de tais direitos básicos (DONNELly, 1984, p. 418). (acréscimo nosso).

\section{Conclusões}

O Direito humano à Cidade se insere na categoria do Direito ao Desenvolvimento, sendo considerado como o ramo do direito que trata de todas as subáreas relativas à fruição dos DESC no contexto urbano. Esse direito, por sua vez, também se reveste de instrumentalidade ao direito de desenvolvimento plural do ser humano, notadamente em sua perspectiva de cidadão. No entanto, há duas décadas vem-se verificando um aviltamento desses direitos, notadamente em um contexto de globalização e economia neoliberal, o qual tem resultado em uma nova forma de exclusão e discriminação mediante a miséria, o desemprego e desabrigo em proporçóes gigantescas, não obstante a previsão do $\mathrm{DaC}$ e $\mathrm{DaD}$ como direitos humanos e a responsabilidade dos Estados em promovê-los.

Paralelamente a esse contexto, as divergências acerca de universalismo e relativismo culturais dos direitos humanos têm, a nosso ver, um potencial alarmante para a fragilização desses direitos como um agravante à conjuntura socioeconômica já verificada. Questôes como Teoria da reserva do Possível podem ser tomadas como argumentos para uma pálida atuação na direção dessa responsabilidade. De maneira que a discussóes entre universalismo e relativismo tornam ainda mais prejudiciais a condição dos direitos humanos para além das realidades sociopolíticas e econômicas existentes. Uma correta compreensão e categorizaçáo da natureza desses direitos, em face das discussóes acima, torna-se imprescindível. Nesse ponto, é imperioso relembrar a aplicabilidade dos atributos dos direitos fundamentais em geral aos próprios direitos humanos ( $\mathrm{DaC}$ e $\mathrm{DaD})$, especialidade a historicidade, a universalidade, irrenunciabilidade e efetividade. No intuito de robustecer a teoria constitucional vinculada a essa categoria de direitos e de ratificar a concepção universal impressa aos mesmos em sua gênese, propôs-se a Teoria da Universalidade de Efetividade Relativa. Nesta, a universalidade se coliga à lista ou previsão in abstrato dos direitos humanos, pela essência que os inspira (dignidade humana), e a relatividade se refere à efetividade desses direitos dentro do contexto socioeconômico, político e cultural de cada sociedade, notadamente quanto aos conflitos de interesses, quando se recorrerá, em ambos os casos a um juízo de ponderaçáo que gradará ou adequará cada direito em face do caso concreto.

$\mathrm{O} \mathrm{DaC}$ e o $\mathrm{DaD}$ se inserem nessa temática e nessa proposição inequivocamente, mormente por se constituírem em nova forma de exclusão e violação de direitos humanos em virtude da conjuntura de desequilíbrio e injustiça sociais verificadas pelas estatísticas 
sobre habitação, emprego, educação, alimentação, entre outros, que demandam políticas públicas mais robustas para efetivação dos DEsC como expressão de assunção de responsabilidade perante seus cidadãos e a ordem internacional. Essa concepção jurídica (universais de efetividade relativa) sobre os direitos humanos e, em especial, $\mathrm{DaC}$ e $\mathrm{DaD}$, bem como uma retomada de açóes na direção dos DESC marca e influi, decisivamente, para forjar e aprimorar o perfil de cidadão livre nos exatos termos da dimensão captada por Amartya $\mathrm{SEN}^{28}$ : liberdade (ampla) como fator de desenvolvimento.

\section{Referências}

Antunes, Eduardo Muylaert. A natureza jurídica da Declaração dos Direitos Humanos. São Paulo: Revista dos Tribunais, n. 446, p. 35.

Ávilla, Humberto. Teoria dos princípios: da definição à aplicação dos princípios jurídicos. São Paulo: Malheiros Editores, 2009.

BArroso, Luís Roberto. Curso de direito constitucional contemporâneo: os conceitos fundamentais e a construção do novo modelo. São Paulo: Saraiva, 2011.

bauman, Zygmunt. Confiança e medo na cidade. Rio de Janeiro: Jorge Zaar, 2009.

Bava, Silvio Caccia. Le Monde Diplomatique Brasil. Ano 7. No. 73.

BRASIL. Constituiçáo da República Federativa do Brasil de 1988.

CASSIN, René. El problema de la realización de los derechos humanos em la sociedade universal. In: Veinte años de evolutión de los derechos humanos. Pamplona: Universidade Nacional Autónoma de México, 1974.

Conpedi. peixeinho, M. Messias e ferraro, Suzani Andrade. Direito ao desenvolvimento como direito fundamental. In: CONSELHO NACIONAL EM PESQUISA E PÓsgraduação em direito, 15., 2006, Manaus. Anais, Manaus: conpedi, 2006, p. 6952-6973.

28 Sobre a relaçáo entre liberdade e cidadania, Fredys fez importante análise histórica, perpassando pelos teóricos e teorias a respeito, motivo pelo qual transcrevemos trecho de seu artigo: "A célebre afirmaçáo de Hannah Arendt de que cidadania é o direito a ter direitos em resposta à ruptura totalitária, como diz Lafer, representa, a despeito de toda a carga positiva da asserçáo humana, apenas um dos lados da questão. Pois não há cidadania sem deveres, nem direitos sem obrigaçóes na comunidade política. [...] A cidadania e a liberdade têm a mesma origem e o mesmo percurso. A modernidade reinventa-as, adaptaas a realidades diferentes. [...] Por outras palavras, a adequada prática da liberdade pressupóe também o imprescindível exercício da autoridade, o que leva a negar também o seu valor absoluto, uma vez que se assim for, o governo deixa de ser legítimo. Além do mais, sem a liberdade a cidadania náo existe, sem a autoridade é impossível qualquer forma de organização política. Ver sorto, Fredys Orlando. O projeto jurídico de cidadania universal: reflexôes à luz do direito de liberdade. Anuário hispano-lusoamericano de derecho internacional, Madrid, vol. 20, p. 105 e 108, ene./dic. 2011. 
DONNELLY, Jack. Cultural relativism and universal human rights. Human Rights Quarterly, vol. 6, n. 4, 1984. Disponível em: www.jstor.org. Acesso em 31 jan 2015.

Douzinas, C. O fim dos direitos humanos. São Leopoldo: Unisinos, 2009.

DWORKin, Ronald. Levando os direitos a sério. São Paulo: Martins Fontes, 2002.

feitosa, M. L. A. M; franco, F. C. O; Peterke, sven; e ventura, V. A. M. F. Direitos humanos de solidariedade: avanços e impasses. Curitiba: Appris, 2013.

FeITosa, Enoque. De como o marxismo lida com a relação entre prescrição e Descrição do mundo e as demandas por sua transformação. Encontro internacional do GT Ética e Cidadania da ANPOF. Pernambuco: ufPe, 2013.

harvey, David. O direito à cidade. Revista Piauí. Ed. 82, jul/2013. Disponível em: http://revistapiaui.estadao.com.br/edicao-82/tribuna-livre-da-luta-de-classes/o-direito-a-cidade.

Lefevbre, Henri. O direito à cidade. 5 ed. São Paulo: Centauro, 2005.

LOSURdo. Domenico. Contra-história do liberalismo. São Paulo: Ideias e Letras, 2006. Hegel, Marx e a tradição liberal. São Paulo: Unesp, 1998.

ONU. Declaração sobre Direito ao Desenvolvimento, 1986.

. Pacto Internacional sobre Direitos Econômicos, Sociais e Culturais, 1966.

. Declaração e Programa de Ação de Viena. Viena, 1993. Disponível em: www. oas.org.br. Acesso em 31 jan 2015.

Agenda Habitat. Vancouver, 1976. Disponível em: http://nacoesunidas.org.br. Acesso em 31 jan 2015.

. Carta das Naçóes Unidas. EUA: São Francisco, 1945. Disponível em: http:// nacoesunidas.org/carta. Acesso em 31 jan 2015.

. Declaraçáo de Istambul sobre assentamentos humanos. Istambul, 1996. Disponível em: http://pfdc.pgr.mpf.mp.br. Acesso em 31 jan 2015.

PIOVESAn, Flávia. Direitos Humanos e o Direito Constitucional Internacional. 9 ed. São Paulo: Saraiva, 2013, p. 28.

. Direitos sociais, econômicos e culturais e direitos civis e políticos. SUR - Revista Internacional dos Direitos Humanos. Ano I, Número I, 2004, p. 22.

. Direito ao desenvolvimento. II Colóquio Internacional de Direitos Humanos. São Paulo, 2002, p. 2.

RISTER, Carla Abrantkoski. Direito ao desenvolvimento: antecedentes, significados e consequências. São Paulo: Renovar, 2007. 
Santos, Boaventura de Sousa. Por uma concepção multicultural de direitos humanos. Coimbra: Revista Crítica de Ciências Sociais, n. 48, jun. 1997.

SARLET, Ingo Wolfgang. A eficácia dos direitos fundamentais. 6 ed. Porto Alegre: Livraria do Advogado, 2006.

. Dignidade da pessoa humana e direitos fundamentais na Constituiçáo Federal de 1988. Porto Alegre: Livraria do Advogado, 2006, p. 84.

SEn, Amartya. Desenvolvimento como liberdade. São Paulo: Companhia das Letras, 2010.

SEngupta, Arjun. O direito ao desenvolvimento como um direito humano. Social Democracia Brasileira, 2002. Disponível em: http://ww1.psdb.org.br/psdb_antigo/ Partido/itv/revista/revista_02/p7292_o_direito.pdf.

TRINDADE, Antônio Augusto Cançado. Desafios e conquistas do direito internacional dos direitos humanos no início do século XXI. In: Tratado internacional dos direitos humanos. Porto Alegre: S. A. Fabris, 2003.

villey, Michel. O direito e os direitos humanos. São Paulo: WMF Martins Fontes, 2007.

VINCENT, R. J. Human rights policy and international relations: realist foundations reconsidered. Utah: University of Utah, 2005.

SORTO, Fredys Orlando. Cidadania e nacionalidade: institutos jurídicos de direito interno e de Direito Internacional. Verba Juris: Anuário da Pós-Grauação em Direito, João Pessoa, ano 8, n. 8, p. 43, jan/dez. 2009.

. A Declaração Universal dos Direitos Humanos no seu sexagésimo aniversário. Verba Juris: Anuário da Pós-Graduação em Direito, João Pessoa, ano 7, n. 7, p. 12 13, jan/dez. 2008.

. O projeto jurídico de cidadania universal: reflexóes à luz do direito de liberdade. Anuário hispano-luso-americano de derecho internacional, Madrid, vol. 20, p. 105 e 108, ene./dic. 2011. 